\title{
Toxicological Effects of Chlorpyrifos on Growth, Chlorophyll a Synthesis and Enzyme Activity of a Cyanobacterium Spirulina (Arthrospira) platensis
}

\author{
G. Rathi Bhuvaneswari ${ }^{1}$, C. S. Purushothaman ${ }^{2}$, P. K. Pandey ${ }^{3}$, \\ Subodh Gupta ${ }^{1}$, H. Sanath Kumar ${ }^{1}$ and S. P. Shukla ${ }^{1 *}$
}

${ }^{I}$ ICAR - Central Institute of Fisheries Education, Mumbai, India

${ }^{2}$ ICAR - Central Marine Fisheries Research Institute, Cochin (Retd), India

${ }^{3}$ College of Fisheries, Central Agricultural University, Lembucherra, India

*Corresponding author

\begin{tabular}{|l|}
\hline Ke y w o r d s \\
Chlorpyrifos, Acute \\
Toxicity, Spirulina \\
\hline Article Info \\
\hline $\begin{array}{l}\text { Accepted: } \\
\text { 20 May 2018 } \\
\text { Available Online: } \\
\text { 10 June 2018 }\end{array}$ \\
\hline
\end{tabular}

\section{Introduction}

India is primarily an agriculture-based country with more than 60-70 per cent of its population dependent on agriculture. India's fast growing population is projected to cross 1.3 billion by 2020 (Kanekar et al., 2004).

In the current agricultural practices, a wide range of pesticides are often extensively used with the aim of increased production. Such pesticides are toxic to humans, plants and animals (Ghosh and Philip 2006). The quantum of organophosphorous insecticide has increased as it serves as an alternative to organochlorine and carbamate pesticides because of their efficiency and relatively lower persistence (Shreekumar et al., 2017). These organophosphorus insecticides can contaminate surface waters through unintentional drift of aerial spraying, surface run off and wet deposition (Sabater and Carrasco, 2001). Environmental contamination due to the excessive use of 
pesticides has become a great concern to the public and to environmental regulatory authorities.

Among the organophosphorous insecticide, one of the widely used insecticide is Chlorpyrifos [0, 0-diethyl 0-3, 5, 6-trichloro 2-pyridinyl-phosphorothioate] (Cho et al., 2002). It is effective against a broad spectrum of insect pests on a variety of crops like cotton, vegetables, fruits, sugarcane, golf turf grass and residential pest control.In India, chlorpyrifos was the second most used agricultural insecticide during 2013 2014,with a production of 9540 tons (Shreekumar et al., 2017. It has low water solubility, $2 \mathrm{mgL}^{-1}$, but it is highly soluble in many organic solvents. Chlorpyrifos has high soil sorption co-efficient $\left(K_{d}=13.4\right.$ to 1862 $\mathrm{mL} / \mathrm{g}$ ) depending on the soil type with a halflife of 10 to 120 days in different soil. (Pandey and Singh, 2004) Like other organophosphorous pesticides, its insecticidal action is due to the inhibition of the enzyme acetylcholinesterase, resulting in the accumulation of the neurotransmitter, acetylcholine, at nerve endings (Kanekar et al., 2004), this results in the excessive transmission of nerve impulses, which causes a potential risk to the humans and other organisms.

Freshwater phytoplankton species show a variable sensitivity to pesticides. Generally, photosynthesis and growth of phytoplankton are negatively affected byexposure to pesticides (Shoaib et al., 2011). It is estimated that these microalgae may account for 40 to $45 \%$ of oceanic production and are considered as more productive than all the worlds' rainforests (Mann, 1999) and any negative impact caused on phytoplankton would have deleterious effect.

These pesticides are often toxic to freshwater organisms found in the environment. Due attention is required to study the impact of organophosphorous insecticide onnontarget organisms in the aquatic environment. Microalgae need special attention considering the ecological position in the food chain. They are at the base of aquatic food web as primary producers. They play a significant role in nutrient cycle and oxygen production (Asselborn et al., 2015). Few reports are available on the effects of chlorpyrifos on nontarget aquatic organisms (Asselborn et al., 2015). Studies conducted reveals that some algae can bioaccumulate pesticide (Subashchandrabose et al., 2013) and hence can play a key role in the transport of this organic contaminants through the food chain to higher trophic levels (Wang and Wang, 2005).

Cyanobacteria, Spirulina platensisa multicellular, filamentous micro algae, with high nutritional value due to rich protein, carbohydrates, essential fatty acids, vitamins, minerals, carotenes, chlorophyll a and phycocyanin, is used as a food supplement for humans and animals. This photosynthetic prokaryotes, which plays a key role in photosynthetic fixation of energy and its transfer to higher trophic levels (Lee et al., 2001).

Researchers have reported that cyanobacterial photosynthesis, growth and heterocyst differentiation is significantly reduced or inhibited by herbicides and pesticides (Shoaib et al., 2012). Due to nutritional, ecological and economic properties Spirulina platensis has been the area of research. (Ali and Saleh, 2012).

The aim of this study was to evaluate the effects of different concentrations of the organophosphorus insecticide chlorpyrifos on the growth, pigment and protein content of the cyanobacterium, Spirulina (Arthrospira) platensis. 


\section{Materials and Methods}

\section{The indoor culture of microalgae}

The indoor batch cultivation of $S$. platensis was carried out in Erlenmeyer flasks (250, 500 and $1000 \mathrm{~mL}$ ). The indoor culture was maintained in plant growth chamber with an illumination of $3500 \pm 100$ lux using compact fluorescent lamps (Philips, $23 \mathrm{~W}$ ). The light intensity was measured using lux meter (LX103, Taiwan). The photoperiod was fixed at 12:12 hour light and dark periods.

The temperature was maintained at $24 \pm 2^{\circ} \mathrm{C}$. The cultures were shaken twice in a day to ensure the proper mixing of the algal suspension. A closed airlift indoor culture unit of $20 \mathrm{~L}$ capacity was used for the continuous culture of algae and the cultures were aerated using an air injection device which supplied air at the bottom of the aspirator bottle, and the air-flow was adjusted to a level that ensured proper mixing of the culture.

\section{Selection of Growth Medium}

The pure culture of $S$. platensis was subcultured in modified Nallayam Research Centre medium (Bhuvaneswari G.R. et al., 2014) under specified photoautotrophic conditionsin indoor airlift cultures. The composition of the growth medium isconsist $5 \mathrm{~g} \mathrm{NaCl}, 2.5 \mathrm{~g} \mathrm{NaNO}_{3}, 0.01 \mathrm{~g} \mathrm{FeSO}_{4} .7 \mathrm{H}_{2} \mathrm{O}$, $0.5 \mathrm{~g} \mathrm{~K}_{2} \mathrm{SO}_{4}, 0.16 \mathrm{~g} \mathrm{MgSO}_{4} .7 \mathrm{H}_{2} \mathrm{O}, 8 \mathrm{~g}$ $\mathrm{NaHCO}_{3}$, and $0.5 \mathrm{~g} \mathrm{~K}_{2} \mathrm{HPO}_{4}$ per litre.

Preparation of stock and working test solution of Chlorpyrifos (CP)

Chlorpyrifos (purity $\geq 99 \%$ Chlorpyrifos), purchased from Sigma Aldrich, the USA was used for the experiments. A stock solution of CP (2000mg L $\left.\mathrm{L}^{-1}\right)$ was prepared freshly prior to the experiment by dissolving required amount of $\mathrm{CP}$ in Acetone.

\section{Toxicity assay}

Toxicity studies were carried out in various concentrations viz. 10, 20, 40, 60, 80 and 100 $\mathrm{mg} \mathrm{L}^{-1}$ of $\mathrm{CP}$ solution. These concentrations were obtained by the appropriate dilution of the stock solution of $\mathrm{CP}$ in respective media. Simultaneously controls were also prepared for each concentration by adding the same amount of acetone to that of test solutions, without $\mathrm{CP}$ in the algal medium.

\section{Algal species and culture conditions}

Toxicity experiment was conducted according to OECD guidelines 201 (OECD, 2006), with certain modifications when necessary. The inoculum of $S$. platensis was prepared in mNRC medium for the experiment, two days before the test to ensure that the algal cells exposed to $\mathrm{CP}$ are in exponential phase.

The exponentially growing algal culture was harvested by centrifugation and resuspended in CP solution of graded concentrations in the medium. The culture density for all the experiments was maintained at $3 \times 10^{5}$ cells $\mathrm{mL}^{-1}$.

Three replicates at each test concentration including control were incubated for $72 \mathrm{hrs}$ under the following photoautotrophic conditions, specified earlier. The cultures were manually shaken twice a day, i.e. in morning and evening to resuspend any settled cells. Samples were analyzed at every $24 \mathrm{hrs}$ time interval by measuring the direct optical density at $750 \mathrm{~nm}$ to calculate the specific growth rate and generation time, SOD activity and protein content using a double beam UVvisible spectrophotometer (MOTRAS Scientific, New Delhi).

The number of algal cells was counted using Sedgewick Rafter cell counter (Partex Products, Mumbai) using a light microscope. 


\section{Analytical procedures}

\section{Specific growth rate and generation time}

The specific growth rate $(\mathrm{K})$ of the alga was calculated by using the formula given by Kratz and Myers (1955):

$\mathrm{K}\left(\right.$ day $\left.^{-1}\right)=\frac{2.303 \log \mathrm{N}_{\mathrm{t}}-\log \mathrm{N}_{0}}{\left(\mathrm{~T}_{\mathrm{t}}-\mathrm{T}_{0}\right)}$

Where $\mathrm{N}_{0}$ is the initial optical density at 750 $\mathrm{nm}$ at time $\mathrm{T}_{0}$ and

$\mathrm{N}_{\mathrm{t}}$ is the final optical density at time $\mathrm{T}_{\mathrm{t}}$ when culture is in exponential phase

The generation time $(\mathrm{G})$ was calculated by using the formula:

$\mathrm{G}($ days $)=\frac{0.693}{------}$

Where $\mathrm{K}$ is the specific growth rate

\section{Test endpoint}

The test endpoint was measured in terms of inhibition of growth, expressed as the logarithmic increase in biomass (in terms of cell counts) during the exposure period. Percent inhibition (in terms of cell counts) was calculated as:

$\% \mathrm{I}=\frac{(\mu \mathrm{c}-\mu \mathrm{t})}{\mu \mathrm{c}}$

Where:

$\% \mathrm{I}=$ Percent inhibition in cell counts;

$\mu \mathrm{c}=$ mean value of cell counts in the control group; $\mu \mathrm{t}=$ mean value of cell counts of the treatment groups

Median effective concentration $\left(\mathrm{EC}_{50}\right)$ of CP for microalgae S. platensis

72-h $\mathrm{EC}_{50}$ of $\mathrm{CP}$ for $S$. platensis was calculated using probit analysis (Finney, 1971). $\mathrm{EC}_{50}$ of CP is the concentration of the test substance that results in 50\% reduction in growth or algal cells within the stated exposure period.

\section{Extraction and analysis of chlorophyll $a$ and carotenoid}

Algal cultures from all controls and treatments of volume $15 \mathrm{~mL}$ were taken after $72 \mathrm{~h}$ exposure with various concentrations of $\mathrm{CP}$ used for toxicity experiment. The cultures were centrifuged (Eltek Microprocessor Highspeed Research refrigerated centrifuge, MP $400 \mathrm{R}$, India) at $7700 \mathrm{~g}$ for 10 minutes at $4^{\circ} \mathrm{C}$.

The supernatants were discarded, and $15 \mathrm{~mL}$ of $\mathrm{N}, \mathrm{N}$-dimethyl formamide (DMF) was added to the remaining pellets and kept for 24$\mathrm{h}$ for incubation at the room temperature. After the incubation, it was centrifuged at $7700 \mathrm{~g}$ for 10 minutes. The supernatants were collected in separate tubes, and optical densities were measured at prescribed wavelengths $(664,647$ and $461 \mathrm{~nm})$. The pigments (chlorophyll-a (Moran, 1982) and carotenoid (Chamovitz et al., 1993)) present in S. platensis was calculated as follows:

Chlorophyll-a $\left(\mu \mathrm{g} \mathrm{mL}^{-1}\right)=\mathrm{OD}_{664} \times 11.92$

Carotenoid $\left(\mu \mathrm{g} \quad \mathrm{mL}^{-1}\right)=\left[\begin{array}{l}\mathrm{OD}_{461} \\ -\end{array}\right.$ $\left.\left(0.046 \times \mathrm{OD}_{664}\right)\right] \times 4$

\section{Enzyme assay}

Assessment of antioxidant enzyme is necessary to estimate the microalgal cell's 
tolerance and response to $\mathrm{CP}$. For this purpose, $5 \mathrm{~mL}$ of the microalgal suspension was withdrawn from the culture at a regular time interval and centrifuged at $4500 \mathrm{rpm}$ for $10 \mathrm{~min}$ at $4^{\circ} \mathrm{C}$. The biomass pellet was washed with distilled water to remove unnecessary traces of the medium and the centrifuged again.

The recovered cell pellet was resuspended in $0.1 \mathrm{M}$ Tris $\mathrm{HCl}(\mathrm{pH} 7.4)$, sonicated for $5 \mathrm{~min}$ at $4^{\circ} \mathrm{C}$ and centrifuged at $10,000 \mathrm{rpm}$ for 10 min. The cell lysate supernatant collected after centrifugation was used to determine the activities of SOD. The amount of enzyme that caused a 50\%decrease in the nitroblue tetrazolium reduction is referred as one unit of SOD activity (Kurade et al., 2016).

\section{Data analysis}

The 72-h median effective concentration $\mathrm{EC}_{50}$ of $\mathrm{CP}$ for $S$. platensis was calculated using probit analysis, SPSS 21.0.

Further, the toxicity experiments were statistically analysed using SPSS 21.0 in which data were subjected to one-way analysis of variance (ANOVA) and when differences observed were significant, the means were compared by Duncan multiple range tests, at a level of significance of 0.05 ( $p<0.05)$.

\section{Results and Discussion}

\section{Influence of $\mathrm{CP}$ on growth rates and generation time}

$\mathrm{CP}$ could suppress the growth of $S$. platensis in a concentration-dependent manner during $72 \mathrm{~h}$ exposure reaction period. Compared with control groups, $\mathrm{CP}$ at all studied concentrations can significantly inhibit the growth of the algae. The specific growth rate of alga was decreased up to $40 \mathrm{mg} \mathrm{L}^{-1}$, while no growth detected at exposure to higher concentration. Generation time $(\mathrm{G})$ presented a similar response pattern to the specific growth rate (Table 1).

\section{Percent growth inhibition}

Based on the number of cells in the controls and treatments, percent inhibition of growth was calculated post 72-h of the experiment. A significant difference $(\mathrm{p}<0.05)$ in percent growth inhibition of $S$. platensis was observed among the various concentrations of $\mathrm{CP}$ exposed groups. Low concentrations $(10 \mathrm{mg}$ $\mathrm{L}^{-1}$ ) of CP had minor effects on the growth of S. platensis. The highest percent inhibition $(54.64 \%)$ occurred at $40 \mathrm{mg}^{-1} \quad \mathrm{CP}$ concentration (Figure 1).

The $\mathrm{EC}_{50}$ for the $\%$ growth inhibition at the end of the bioassay was calculated and was found as $33.65 \mathrm{mg} \mathrm{L}^{-1}$ of $\mathrm{CP}$ with a confidence interval $(95 \%)$.

Effect of CP on chlorophyll- $a$ and carotenoid content

The content and composition of pigment were measured after 72-h of exposure to $\mathrm{CP}$. The pigments, chlorophyll- $a$, and carotenoids were measured and found to have significant $(p<0.05)$ reduction in level in all the CP exposed groups when compared with control. The chlorophyll- $a$ was $9.37 \mu \mathrm{gmL}^{-1}$ in control (Table 2) wherein it was reduced to 6.53 $\mu \mathrm{gmL}^{-1}$ in highest of CP i.e. $40 \mathrm{mg} \mathrm{L}^{-1}$. A 32.2 $\%$ decrease in the Chlorophyll- $a$ content was recorded in $40 \mathrm{mg} \mathrm{L}^{-1}$ (Fig 2) CP exposed group in comparison to control. The carotenoids content ranged from 3.10 to1.66 $\mu \mathrm{gmL}^{-1}$ in control and treatments. The carotenoids content was significantly reduced in comparison to control and among treatment, and also significant between treatments was found in a dose-dependent manner. The carotenoid content was reduced by $48.33 \%$ in exposure to $40 \mathrm{mgL}^{-1}$ concentration. 
Table.1 Growth rates of $S$. platensis after $72 \mathrm{~h}$ exposure to various concentration of CP

\begin{tabular}{|c|c|c|}
\hline $\begin{array}{c}\text { Concentration of } \\
\mathrm{CP}\left(\mathrm{mg} \mathrm{L}^{-1}\right)\end{array}$ & SGR $\left(\right.$ day $\left.^{-1}\right)$ & $\begin{array}{c}\text { Generation Time } \\
\text { (days) }\end{array}$ \\
\hline 0 & $0.24^{\mathrm{b}} \pm 0.02$ & $2.88^{\mathrm{a}} \pm 0.19$ \\
\hline 10 & $0.23^{\mathrm{b}} \pm 0.01$ & $3.01^{\mathrm{a}} \pm 0.03$ \\
\hline 20 & $0.13^{\mathrm{a}} \pm 0.01$ & $5.21^{\mathrm{b}} \pm 0.07$ \\
\hline 40 & $0.10^{\mathrm{a}} \pm 0.01$ & $6.84^{\mathrm{c}} \pm 0.67$ \\
\hline
\end{tabular}

Table.2 Effect of various concentrations of $\mathrm{CP}$ on the pigment composition of S.platensis

\begin{tabular}{|l|l|l|}
\hline Concentration of $\mathrm{CP}\left(\mathrm{mgL}^{-1}\right)$ & $\mathrm{Chl}$ a $\left(\mu \mathrm{gmL}^{-1}\right)$ & Carotenoids $\left(\mu \mathrm{gmL}^{-1}\right)$ \\
\hline 0 (control) & $9.37^{\mathrm{b}} \pm 0.27$ & $3.10^{\mathrm{c}} \pm 0.11$ \\
\hline 10 & $8.88^{\mathrm{b}} \pm 0.64$ & $2.90^{\mathrm{c}} \pm 0.01$ \\
\hline 20 & $8.40^{\mathrm{b}} \pm 0.09$ & $2.38^{\mathrm{b}} \pm 0.23$ \\
\hline 40 & $6.53^{\mathrm{a}} \pm 0.16$ & $1.66^{\mathrm{a}} \pm 0.05$
\end{tabular}

Data are represented in mean $\pm S E, n=3$. The data labels represent the significant difference $(p<0.05)$.

Fig.1 Percent inhibition of growth in S. platensis exposed to different concentration of CP

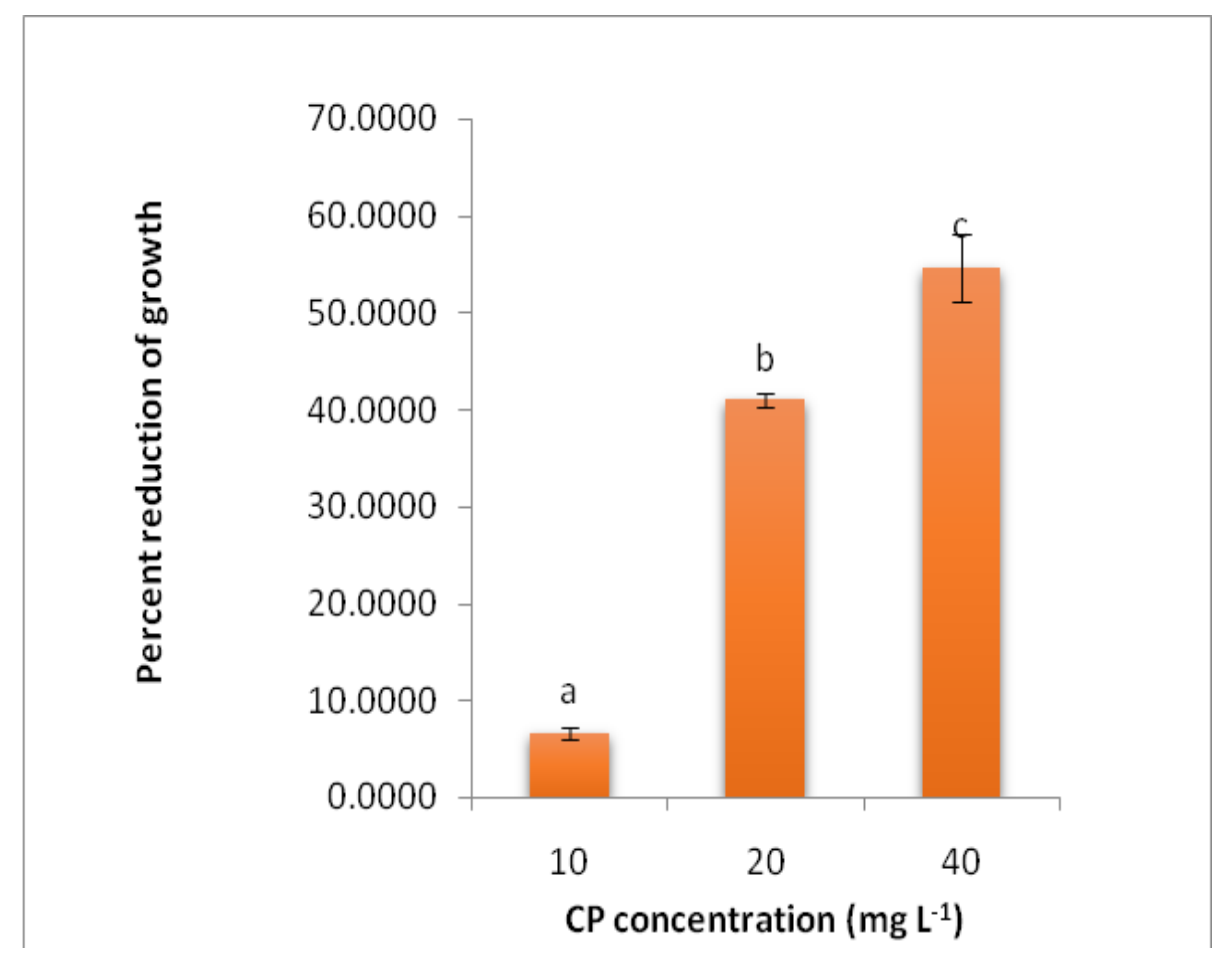


Fig.2 Effect of various concentrations of CP on the pigment composition of S. platensis. Data are represented in mean $\pm S E, n=3$. The data labels represent the significant difference $(\mathrm{p}<0.05)$

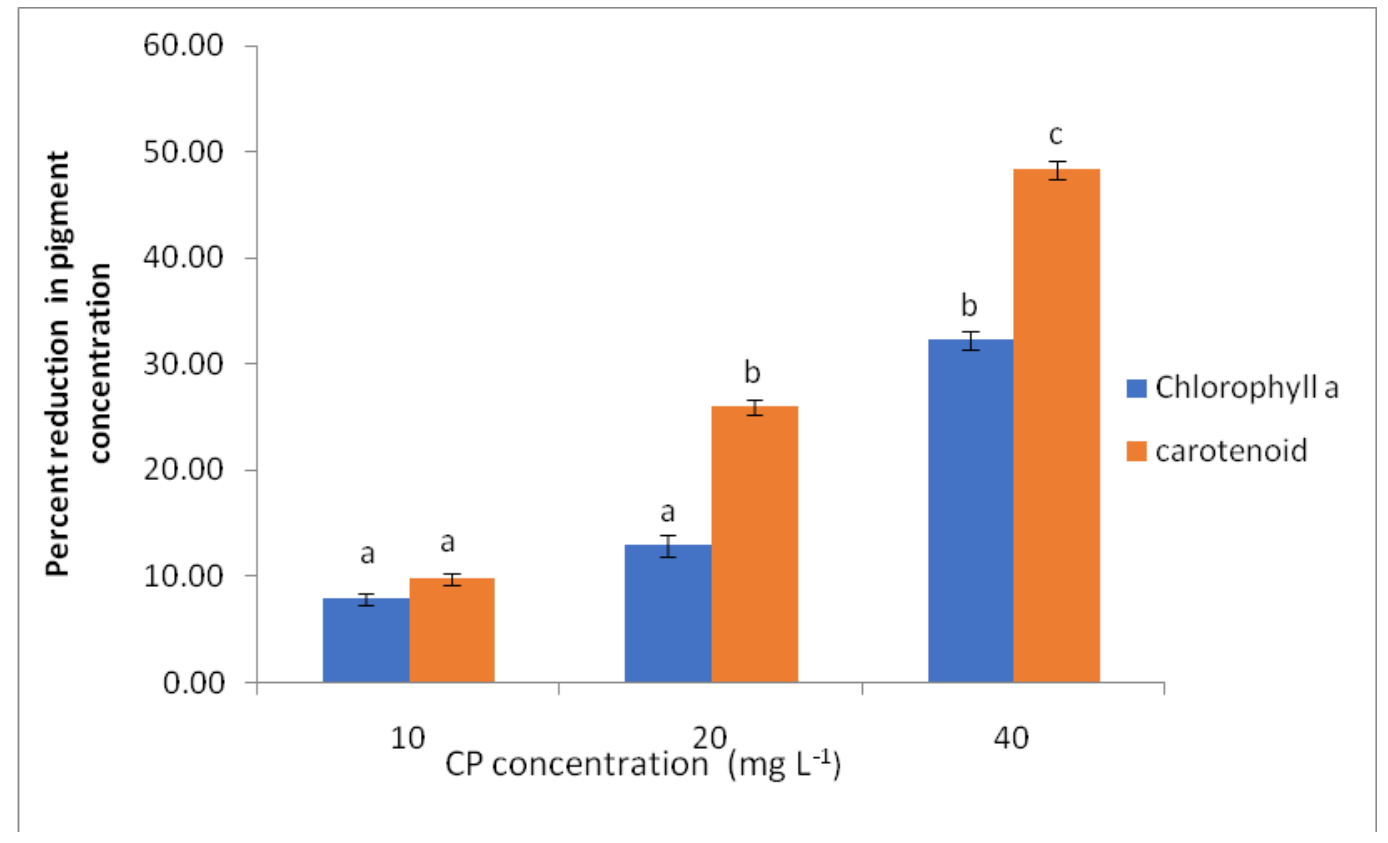

Fig.3 Effect of Chlorpyrifos on SOD Enzyme

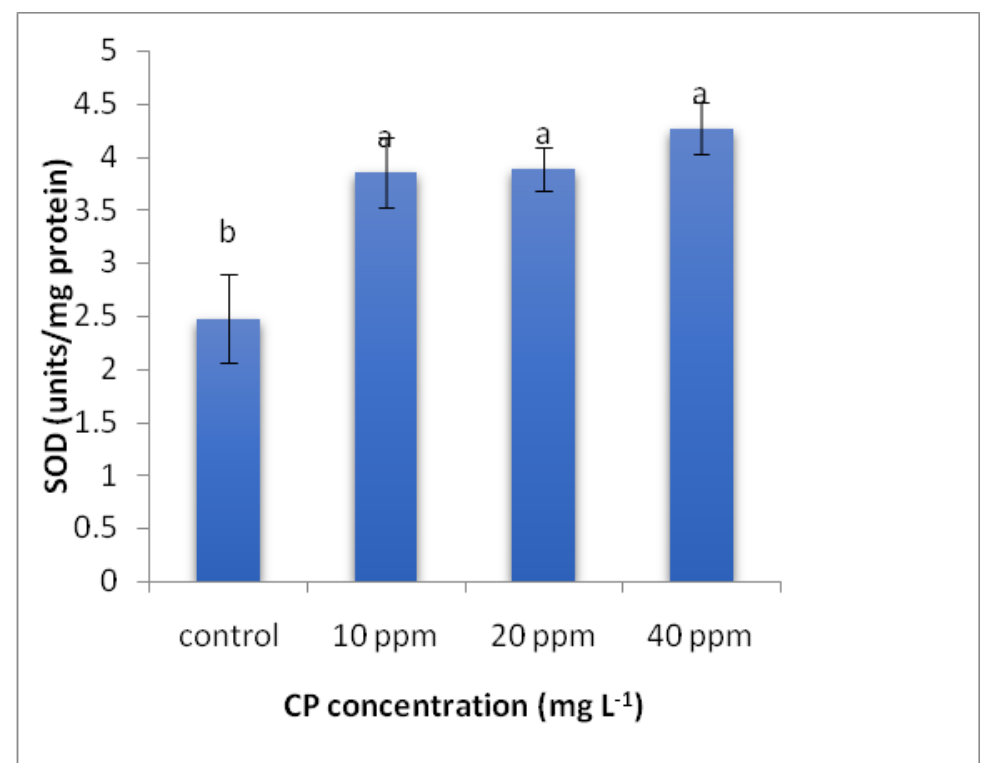

\section{Effect on Antioxidant Enzyme -SOD}

The SOD activity in S.platensis cells in the presence of $\mathrm{CP}$ was enhanced due to the exposure to various concentration over the untreated cells. There was significant $(\mathrm{p}<0.05)$ increase in SOD enzyme activity between the control and treatment (Fig 3). However, there was no significant difference was found between the treatments.

The microalgae, which are the primary producers and in the base of the aquatic food chain, plays a key role in the structure and 
function of an ecosystem. Among the aquatic organisms, it is reported that sensitivity of algae and cyanobacteria are high. They are very important indicators used to assess the toxicity of chemicals released to the aquatic environment (Burkiewicz K., 2005). To understand the toxicity of a compound, algal toxicity tests are widely used based on assessing the growth inhibition of the microalgae.

In the present study, the toxicity of $\mathrm{CP}$ to $S$. Platensis was evaluated by phytotoxicity tests based on growth inhibition, the percent reduction in the growth of algae with pesticide culture compared with control cultures without the pesticide as reported by Oliveira et al., (2007). At higher concentration of pesticide, there was a highly significant reduction of Specific growth rate and proportionate increase in percent inhibition of growth was observed. This could be because of the change in the proportion of pesticide concentration and the existing number of algal cells (Oterler et al., 2016). This dose-dependent reduction in growth was observed by many researchers (Asselborn et al., 2015; Wang and Wang, 2016).

The commission of the European Communities (1996) classified different toxic classes based on the $\mathrm{EC}_{50}$ value of the toxicant. Based on that $\mathrm{CP}$ is found to be harmful to S.platensis because the $\mathrm{EC}_{50}$ value is $33.65 \mathrm{mgL}^{-1}$ which is in the classified range (10-100 $\mathrm{mgL}^{-1}$ ). Wang and Wang (2016) found the $\mathrm{EC}_{50}$ value ranging from 27.80 $\mathrm{mg} / \mathrm{L}(24 \mathrm{~h})$ to $25.80 \mathrm{mg} / \mathrm{L}(72 \mathrm{~h})$ in a cyanobacterial species (Merismopedia $s p$ ) against chlorpyrifos. Sun et al., (2015) found the EC50 value of a cyanobacterium which is $21.13 \mu \mathrm{mol} \mathrm{L}{ }^{-1}$, which is too low compared to our results.

Chlorophyll is considered as the sensitive biomarker when exposed to toxicants because of their role in photosynthetic electron transport activity (Huang et al., 2012). Organophosphorus insecticides are known to affect the photosynthetic process of microalgae by interfering with the synthesis of chlorophyll a (Caceres et al., 2008). The growth, synthesis of chlorophyll $a$ and the photosynthetic process of the microalgal cells was significantly inhibited at high concentrations of CP (Wong and Chang, 1988). Our results are in agreement with Oterler, (2016) as he also found a negative correlation of Chlorophyll content with increase in pesticide concentration. A similar pattern of drop-in Chlorophyll_a content and decreased synthesis in the cells causing decreased protein content was found in the results of the studies conducted by $\mathrm{Ou}$ et al., (2003) and Xia et al., (2007). Chlorophyll content is directly related to the biomass. Hence, logically, the reduction in biomass obviously leads to decrease in Chlorophyll concentration.

Carotenoid also serves as sensitive biomarkers for monitoring aquatic contaminants. Its role is to deactivate the excited chlorophyll to avoid the stressinduced damage of the photosynthetic system triggered by the formation of reactive oxygen species (ROS) with exposure to toxicants (Xiong et al., 2016). Like, the reduction in chlorophyll pigments, carotenoids content also was greatly inhibited at relatively high concentrations of $\mathrm{CP}$ indicating $\mathrm{CP}$ is toxic to S. Platensis metabolism which is supported by the results of the study by Asselborn et al., (2015). Our results shows that \% decrease in carotenoid content is higher than the \% decrease in chlorophyll- $a$ content, revealing that carotenoid is more sensitive to $\mathrm{CP}$ than chlorophyll- $a$. The decrease in carotenoid contents might be associated with the lipid peroxidation along with the potassium leakage at high concentrations of organophosphorus pesticide as reported by 
Chen et al., (2011) and Kurade et al., (2016). Singh et al., (2013) found that the herbicide Anilofos caused inhibitory effects on photosynthetic pigments of the test organism in a dose-dependent manner. The organism exhibited 60, 89, 96, 85 and $79 \%$ decrease in chlorophyll a, carotenoids, phycocyanin, allophycocyanin and phycoerythrin, respectively, in $20 \mathrm{mg} \mathrm{L}^{-1}$ anilofos on day six. Their findings support our results well.

The SOD activity in $S$. platensis cells in the presence of $\mathrm{CP}$ was enhanced due to the exposure to various concentration of $\mathrm{CP}$ overuntreated cells. This result is in agreement with various researchers, as they have found significant and progressive increase in SOD activity to the increasing concentration of pesticide (Asselborn et al., 2015; Kurade et al., 2016). Many researchers had proved that organic pollutants tend to stimulate overproduction and accumulation of reactive oxygen species (ROS), including superoxide anions $\left(\mathrm{O}_{2}{ }^{--}\right)$and hydrogen peroxide $\left(\mathrm{H}_{2} \mathrm{O}_{2}\right)$ (Torres et al., 2008). Once the microalgal cells are exposed to pollutants, the cellular detoxification system is initiated by synthesis of SOD to put an end to the toxic stress caused due to ROS (Li et al., 2009).

Superoxide dismutase (SOD) serve as sensitive biomarkers, which can be used as early warnings of pollution. It the first line of defense system of the cell against ROS, catalyses the disproportionation of superoxide anions $\mathrm{O} 2 \cdot-$, to produce $\mathrm{H}_{2} \mathrm{O}_{2}$ and $\mathrm{O}_{2}$. This is followed by the action of catalase which disintegrate hydrogen peroxide into water and oxygen. If these enzymes SOD and catalase fails to catalyse the process of disintegration of ROS it may lead to programmed cell death (Torres et al., 2008). An increase in the SOD levels of microalgae as a response to oxidative stress induced by pesticides has been reported earlier (Singh et al., 2013; Kurade et al., 2016).
The present study demonstrates that the exposure of microalgae to the insecticide Chlorpyrifosposes negative impact. The growth of $S$. platensis was inhibited after the exposure to different concentrations of $\mathrm{CP}$ with the specific growth rate decreasing progressively upon the increase in the pesticide concentration. There was also a significant difference between the control and treatment in parameters like percent growth reduction, Chlorophyll $a$, carotenoid and antioxidant enzymes. Thus, it reveals that effects of Chlorpyrifos are not only restricted to target organisms but also causes an adverse impact on non-target organisms especially phytoplankton, which plays an important role in the functioning of aquatic ecosystems as sole primary producers.

\section{References}

Ali, S.K. and Saleh, A.M., 2012. Spirulinaan overview. Int $J$ Pharm Pharm Sci, 4(3), pp.9-15.

Asselborn, V., Fernández, C., Zalocar, Y. and Parodi, E.R., 2015. Effects of chlorpyrifos on the growth and ultrastructure of green algae, Ankistrodesmusgracilis. Ecotoxicology and environmental safety, 120, pp.334341.

Bhuvaneswari, G. Rathi, S. P. Shukla, M. Makesh, S. Thirumalaiselvan, S. Arun Sudhagar, D. C. Kothari, and Arvind Singh, 2013. "Antibacterial Activity of Spirulina (Arthospiraplatensis Geitler) against Bacterial Pathogens in Aquaculture." Israeli Journal of Aquaculture-Bamidgeh 65 :1-8.

Burkiewicz K., Synak R. andTukaj Z. Toxicity of Three Insecticides in a Standard Algal Growth

Cáceres, T., Megharaj, M. and Naidu, R., 2008. Toxicity and transformation of fenamiphos and its metabolites by two micro algae Pseudokirchneriella 
subcapitata and Chlorococcum sp. Science of the total environment, 398(1-3), pp.53-59.

Chamovitz, D., Sandmann, G. and Hirschberg, J., 1993. Molecular and biochemical characterization of herbicide-resistant mutants of cyanobacteria reveals that phytoene desaturation is a rate-limiting step in carotenoid biosynthesis. Journal of Biological Chemistry, 268(23), pp.17348-17353.

Chen, H. and Jiang, J.G., 2011. Toxic effects of chemical pesticides (trichlorfon and dimehypo) on Dunaliellasalina. Chemosphere, 84(5), pp.664-670.

Chen, W.J. Zheng, Y.S. Wong, F. Yang, (2008). Selenium-induced changes in activities of antioxidant enzymes and content of photosynthetic pigments in Spirulina platensis.J. Integr. Plant Biol. 50: 40-48.

Cho, C. M., Mulchandani, A. and Chen W., 2002. Bacterial cell surface display of organophosphorus hydrolase for selective screening of improved hydrolysis of organophosphate nerve agents. ApplMicrobiolBiotechnol., 68: 20262030.

Finney, D.J., 1971. Probit Analysis. Cambridge University Press, London.

Ghosh, P. K. and Philip, L., 2006. Environmental significance of atrazine in aqueous systems and its removal by biological processes: An overview. Global NEST Journal, 8: 159-178.

Huang, L., Lu, D., Diao, J. and Zhou, Z., 2012. Enantioselective toxic effects and biodegradation of benalaxyl in Scenedesmus obliquus. Chemosphere, 87(1), pp.7-11. Inhibition Test with Scenedesmus subspicatus, Bull. Environ. Contam. Toxicol., 74, 1192-1198, (2005). J.Integr. Plant Biol. 50 (2008) 40-48.
Kanekar, P. P., Bhadbhade, B., Deshpande, N. M. and Sarnaik, S. S., 2004. Biodegradation of organophosphorus pesticides. Proc Indian NatnSci Acad., 70: 57-70.

Kratz, W. A., Myers, J. (1955): Nutrition and growth of several blue green algae. Amm. J. Bot. 42, 282-287.

Kurade, M.B., Kim, J.R., Govindwar, S.P. and Jeon, B.H., 2016. Insights into microalgae mediated biodegradation of diazinon by Chlorella vulgaris: Microalgal tolerance to xenobiotic pollutants and metabolism. Algal research, 20, pp.126-134.

Lee, O.H., Williams, G.A. and Hyde, K.D., 2001. The diets of Littorariaardouiniana and L. melanostoma in Hong Kong mangroves. Journal of the Marine Biological Association of the United Kingdom, 81(6), pp.967-973.

Li, X., Ping, X.M. Sheng, Z.B.Wu, L.Q. Xie, (2005). Toxicity of cypermethrin on growth, pigments, and superoxide dismutase of Scenedesmus obliquus, Ecotoxicol. Environ. Saf.60: 188-192.

Lowry, O.H., Rosebrough, N.J., Farr, A.L. and Randall, R.J., 1951. Protein measurement with the Folin phenol reagent. Journal of biological chemistry, 193(1), pp.265-275.

Mann, D.G. 1999. The species concept in diatoms. Phycologia, 38(6): 437-495.

Moran, R., Porath, D., 1980. Chlorophyll determinations in intact tissue using N,N-dimethylformamide. Plant Physiol. $65,478-479$.

Öterler, B. and Albay, M., 2016. The effect of 5 organophosphate pesticides on the growth of Chlorella vulgaris Beyerinck [Beijerinck] 1890. International Journal of Research Studies in Biosciences. 4, pp.26-33.

Pandey, S. and Singh, D. K., 2004. Total bacterial and fungal population after chlorpyrifos and quinalphos treatments in 
groundnut (Arachis hypogaea) soil. Chemosphere, 55:

Sabater, C. and Carrasco, J.M., 2001. Effects of the organophosphorus insecticide fenitrothion on growth in five freshwater species of phytoplankton. Environmental toxicology, 16(4), pp.314-320.

Shoaib, Nafisa, Pirzada Jamal Ahmed Siddiqui, and Halima Khalid, 2012 "Toxicity of chlorpyrifos on some marine cyanobacteria species." Pakistan Journal of Botany, 43:1131-1133.

Shoaib, Nafisha., Jamal, P., Siddiqui, A., Ali, A., Burhan, Z.U.N. and Shafique, S., 2011. Toxicity of pesticides on photosynthesis of diatoms. Pakistan Journal of Botany, 43(4), pp.2067-2069. Singh, D.P., Khattar, J.I.S., Kaur, M., Kaur, G., Gupta, M. and Singh, Y., 2013. Anilofos tolerance and its mineralization by the cyanobacterium Synechocystis sp. strain PUPCCC 64. PLoS One, 8(1), p.e53445.

Sreekumar, S. and Devatha, C.P., 2017. Biodegradation of Chlorpyrifos from agricultural soil. Journal of Emerging Research in Management \&Technology, 6: 2278-9359.

Subashchandrabose, S.R., Ramakrishnan, B., Megharaj, M., Venkateswarlu, K. and Naidu, R., 2013. Mixotrophic cyanobacteria and microalgae as distinctive biological agents for organic pollutant degradation. Environment international, 51, pp.59-72.
Sun, K.F., Xu, X.R., Duan, S.S., Wang, Y.S., Cheng, H., Zhang, Z.W., Zhou, G.J. and Hong, Y.G., 2015. Ecotoxicity of two organophosphate pesticides chlorpyrifos and dichlorvos on non-targeting cyanobacteria Microcystis wesenbergii. Ecotoxicology, 24(7-8), pp.1498-1507

Torres, M.A., M.P. Barros, S.C.G. Campos, E. Pinto, S. Rajamani, R.T. Sayre, P. Colepicolo, (2008). Biochemical biomarkers in algae and marine pollution: a review, Ecotoxicol. Environ. Saf. 71: 1-15.

Wang, X. and Wang, W.X., 2005. Uptake, absorption efficiency and elimination of DDT in marine phytoplankton, copepods and fish. Environmental Pollution, 136(3), pp.453-464.

Wong, P.K. and Chang, L., 1988. The effects of 2, 4-D herbicide and organophosphorus insecticides on growth, photosynthesis, and chlorophyll a synthesis of Chlamydomonas reinhardtii (mt+). Environmental Pollution, 55(3), pp.179-189.

Xiong, J.Q., Kurade, M.B., Abou-Shanab, R.A., Ji, M.K., Choi, J., Kim, J.O. and Jeon, B.H., 2016. Biodegradation of carbamazepine using freshwater microalgae Chlamydomonas mexicana and Scenedesmus obliquus and the determination of its metabolic fate. Bioresource technology, 205, pp.183-190.

\section{How to cite this article:}

Rathi Bhuvaneswari G., C. S. Purushothaman, P. K. Pandey, Subodh Gupta, H. Sanath Kumar and Shukla S. P. 2018. Toxicological Effects of Chlorpyrifos on Growth, Chlorophyll a Synthesis and Enzyme Activity of a Cyanobacterium Spirulina (Arthrospira) platensis. Int.J.Curr.Microbiol.App.Sci. 7(06): 2980-2990. doi: https://doi.org/10.20546/ijcmas.2018.706.351 